\title{
Effect of Base Erosion and Profit Shifting on Revenue Generation in Nigeria
}

\author{
Olaoye Clement Olatunji*, Adebayo Omolola Christiana \\ Department of Accounting, Ekiti State University, Nigeria
}

Received March 11, 2020; Revised April 20, 2020; Accepted April 27, 2020

Copyright $\subseteq 2020$ by authors, all rights reserved. Authors agree that this article remains permanently open access under the terms of the Creative Commons Attribution License 4.0 International License

\begin{abstract}
This study examined the effect of Base Erosion and Profit Shifting BEPS) on revenue generation in Nigeria. This study employed ex-post facto research design and data were sourced from the CBN Statistical Bulletin of 2017, Security and Exchange Commission (SEC) annual bulletin and the Federal Inland Revenue Services (FIRS) annual reports. Quarterly data were gathered on tax revenue and Gross Domestic Product of Nigeria from 2013-2017. Specifically, data collected on tax revenue were divided into PRE-BEPS (from the third quarter of 2013 to the third quarter of 2015) and POST-BEPS (from the fourth quarter of 2015 to the fourth quarter of 2017). The study covers nine quarters before the introduction of BEPS and nine quarters after the introduction of the BEPS. Data gathered were analyzed via mean, standard deviation, paired t-test and simple linear regression. The findings revealed that there was a positive significant difference between tax revenue generated before and after the introduction of Basic Erosion Profit Sharing (BEPS) in Nigeria to the tune of 0.033 and that ax revenue exerts a significant positive effect on Nigeria's economy to the tune of $10.9030(\mathrm{p}=0.0001<0.05)$. It was established that BEPS can improve tax revenue in Nigeria. Thus, it was recommended that multinationals and other firms should willingly comply with regulations on tax revenue and transfer pricing. This might increase the revenue pool of the Nigerian government needed for the desired level of growth and development.
\end{abstract}

Keywords Base Erosion, Profit Shifting, Revenue Generation

\section{Introduction}

\section{Background of the Study}

International aspects of corporate taxation have recently come to prominence in public debate, prompted largely by increased awareness of the relatively small amounts of tax that, as a result of cross-border tax planning, many multinational enterprises pay (Criveli, Keen \& Mooji 2015). The issue itself, of course, is not new. What is new is the attention it is receiving from policy makers. The G20-OECD project on base erosion and profit shifting (BEPS) carried out in fifteen areas, was revealed to be an unmatched effort to support the international business tax system by restraining occasions for avoidance by multinationals (OECD, 2013). This implies that there is a heightened awareness of the degree of international tax opposition, and the probability of reciprocated damage from the efforts of each country to make its tax system more desirable than others.

Base erosion and profit shifting (BEPS) can be defined as tax avoidance by multinational enterprises (MNEs), which makes use of cracks in the interface of various tax systems to falsely decrease taxable income or to shift profits to low-tax authorities in which little or no economic activity is performed (OECD 2013a). In essence, BEPS entails movement of profit or income from one country to another, in such a way that the country where their tax rate is lowest would be the country where their profit is moved. Observably, it has been on the main agenda of the international community and national governments for decades to restrain BEPS and preserve countries' tax bases. Shah (2010) noted that for some years, there have been budgetary deficits resulting from the 2007/2008 global financial crisis, which brought international concern about restraining BEPS to the forefront. This also prompted the Organisation for Economic Cooperation and Development (OECD) to issue a report in 2013 in which it stated that BEPS is a grave risk to tax revenue, tax dominion and tax impartiality (OECD, 2013).

Base Erosion and Profit Shifting (BEPS) approach focuses attention on some important aspects; to provide consistency in tax system internationally; to make sure that there is an economic substance in international operations 
and to ensure transparency in relation to necessary taxpayers' information for tax revenues administration and to empower tax investigation effort. There have been worries worldwide, about corporations making profits in a particular country but not rendering taxes to the government of the country, or paying less than expected. The Organization for Economic Cooperation and Development (OECD, 2014) asserted that BEPS would greatly assist developing countries due to their heavy dependence on corporate income tax (CIT), especially from multinational corporations. Vijayakumar (2016) reveals that firms make a profit in one jurisdiction and shift them across borders by exploiting gaps and mismatches in tax rules, to take advantage of lower tax rates and, thus not paying taxes to in the country where the profit is made. The international tax system needed a serious overhaul to stop the "bleeding" and catch up with the realities of a globalized economy.

Multinational Companies operate certain portions of their business in different countries, and strategically handle their business between countries to reduce their tax bill. Corporations exploit mismatches between nations where they conduct businesses to generate benefits from double non-taxation. Corporations also utilize the digital economy to sell goods in a place where they have no physical presence, which often means profits from such sales are not taxed in that country. The OECD has begun to address these issues through BEPS project to ensure corporations are paying their fair share of taxes. While BEPS issues go beyond those created by transfer pricing, transfer pricing has been a central component of the discussion on how to address BEPS (Salihu, Annuar \& Obid 2015).

BEPS is hurting the global economy in a number of ways, including depriving nations of valuable income needed to jumpstart growth. Further, the use of BEPS strategies creates a sense of distrust among citizens who may, in turn, question the overall fairness of the tax system. Furthermore, some researchers believe that the economic effects spread and cause a decline in employment, innovation, and productivity when post-tax profit becomes the main attractor for investment (Salihu, Annuar and Obid 2015). Profit shifting by multinationals poses greater challenges to revenue generation in developing nations including Nigeria as Multinationals use this strategy to divert profits to countries in order to reduce tax or for avoidance purposes

Studies like Dowd, Landefeld, and Moore (2017), Crivelli, Mooij and Keen (2015), Salihu, Annuar and Obid (2015) and Purba (2018) have been conducted in this context in the developed countries. However, based on the researcher's knowledge, just a single study, Olaoye and Aguguon (2017), has been conducted on base erosion and profit shifting in Nigeria. Interestingly, this study was a qualitative one hence, empirical studies on the effects of base erosion and profit shifting on revenue generation are lacking to the best of the researchers' knowledge. This, therefore, constituted the premise on which this study was developed to examine the effect of base erosion and profit shifting on revenue generation in Nigeria and equally investigate the effect of tax revenue on the economy of Nigeria.

\section{Literature Review}

This section presents a review of the existing studies that are relevant to this study.

\subsection{Transfer Pricing}

Transfer pricing seems to be a global phenomenon and conceptually, many definitions have been put forward by scholars. Rainish, Mensz and Mohs (2015) opined that transfer prices are viewed as the sum charged for goods and services traded between departments or units of the same company. In the same vein, transfer pricing creates the medium for international corporations to move profits from high tax authorities to lower tax authorities. In essence, this would significantly reduce the tax burden, which in turn upturns value by increasing the general value and profitability (Adams \& Dirtina, 2010). Globally, the uniform accepted method for deciding a transfer price is known as the arms-length method. The arms-length pricing standard shows the price at which two unconnected entities decide to perform a deal in an open market transaction. The arms-length standard was established on the perception of equivalent. Section 482 of the Internal Revenue Code and the rules propagated there, provides in part for the calculation of equivalent. The perception of equivalent is that connected party pricing should be equal to open market pricing.

Mutti and Grubert (2004) opined that despite the circumstances that countries, globally, use the arms-length method to decide transfer prices, they often endorse rules that can give various meanings to what the price or the standard would be. This implies that matching the rules and regulations of one country does not create assurance that other country's specifications would be met. In a bid to tackle these variations, the Organization for Economic Co-operation and Development (OECD) member countries ventured on regular research connected with the different prospects of base erosion (see OECD A-J, 2015). In addition, transfer pricing also includes would-be rent and sale of tangible and intangible property between members of a controlled group as reviewed below.

\subsection{Tax Based Erosion}

The notion of Tax Based Erosion (TBE) has created diverse opinions, which are contradictory sometimes. This is not new in the transfer pricing research. Vijayakumar (2016) asserted that some corporations who create and 
provide wealth in one country, plan to shift those gains across borders by manipulating loopholes in tax rules. They take advantage of lower tax rates in another country other than where the profit was initially made. Organization for Economic Co-operation and Development, OECD, (2014) affirmed that base erosion and profit shifting is a condition or circumstance of tax avoidance that manipulates any created openings and disparities in tax rules to shift gains to another low or no tax environment or locality. This issue of tax avoidance by shifting profits or gains from a nation of high tax jurisdiction to the one of low tax jurisdiction made the OECD consider the option of BEPS; stating that BEPS is a breakthrough for developing economies due to their significant dependence on international income taxes.

OECD (2014) asserted that for the internationals to counter the issue of corporate transfer pricing, there is the need to formulate good and acceptable transfer pricing strategies and try to properly execute them to match the specifications of business strategy and other necessary internal incentives. These strategies would help in the effective use of resources; ensure that there is suitable and accurate transfer pricing from the tax perspective. Transfer pricing usually has disapproving implications, which shows that big multinationals have the autonomy to control the prices on their intra-organizational trade and services for selfish business advantage (Plasschaert, 1997).

\subsection{Overview of Profit-Shifting Techniques and Incentives}

Profit shifting happens in cases where the distribution of profits across a MNE's affiliates does not disclose the true value added in each affiliate; that is, benefits may be stated in a country where the related economic action and value addition did not take place (Riedel, 2014). The tax motive to usually shift profits is fundamentally inspired by variations in the corporate tax rates across tax jurisdictions (Huizinga \& Laeven, 2008). Implicitly, profit-shifting motives are inspired by the tax differences between subsidiaries. This motive to transfer profits from the high-tax subsidiary to the low-tax affiliate exists until the point at which there are no profits left in the high-tax affiliate; that is, till the point where even losses are not taxed.

Olaoye and Aguguon (2017) agreed that some mechanisms can be used. However, they have a common feature: they simulate that the economic activity and related value increase of the MNEs take place in another location than where it takes place. One way of achieving this is by transfer mispricing. To properly comprehend transfer mispricing, it is vital to know that the economic (non-tax, non-monopoly) justification of MNEs is that they can manipulate internal collaborations. This normally entails trading services (administration, know-how, finance, etc.) and goods internally (Purba, 2018).
These services and goods according to the OECD model tax convention should be traded at arms-length prices. Therefore, international corporations should price them 'as if' they were trading with an unconnected entity. In reality, it may be hard for tax jurisdictions to formulate the arms-length price as there may not be any equivalent service traded outside a particular MNE, and goods may vary in quality (Purba, 2018). This permits MNEs to trade goods and services at a price that is altered from the 'true' arms-length price. To reduce global tax payments, the MNE can make the price high, when a high-tax affiliate is importing from a connected low-tax subsidiary, and vice versa. Profits will thus be transferred from the high-tax subsidiary to the low-tax subsidiary without any difference in activities. Empirical research reviewing the actual unit prices of goods highly recommended that methodical transfer mispricing of goods and services does occur in western countries (Cristea \& Nguyen, 2015; Hebous \& Johannesen, 2015).

Another profit-shifting tactic is the transferring of revenue-generating assets and expense-generating liabilities, especially debt and intellectual property. Debt shifting happens when MNEs use corporate finance structuring tactics to transfer profits from high-tax subsidiaries to low-tax affiliates. If a subsidiary in a high-tax country receives debt from an affiliate in a low-tax country, the MNE is capable of transferring income from the high-tax country to the low-tax country. Debt transferring can be viewed also as when a high-tax affiliate takes on external debt that is guaranteed by low-tax affiliates (Huizinga \& Laeven, 2008). There is extensive evidence of debt shifting occurring in European multinationals (Buettner 2012; Huizinga \& Laeven, 2008).

In relation to debt shifting, intellectual property-right shifting is the tactical transfer of intellectual property rights from high-tax to low-tax subsidiaries, such that royalty payments (external and connected) are rendered to the low-tax subsidiaries in the MNE. The intellectual property rights can be transferred by manipulating the source of the property-right or by shifting the property-right at a price that does not match the actual value. Both mechanisms are hard for tax authorities to prove. Likewise, there is systematic empirical evidence of such behaviour within European MNEs (Huizinga \& Laeven, 2008; Karkinsky \& Riedel, 2012).

Theoretically, MNE will transfer profits to the extent where the marginal cost of transferring one more dollar matches the marginal gain (i.e. the tax differences). It is naturally assumed that the marginal cost of profit shifting rises with the amount shifted (Johannesen et al. 2016). A rise in the tax differences would thus heighten the profit from profit shifting and result in more profit shifting. From the perspective of a high-tax country, a rise in the domestic tax rate or a deduction in the foreign affiliate tax rate would result in more profits being shifted out of the country to the low-tax affiliate. That is, a lower foreign affiliate tax rate 
means that fewer profits are reported in the domestic country. In addition, as legal costs increase the marginal cost of profit shifting, governments can competently reduce profit-shifting responses by making it costly.

\subsection{BEPS Implementation in Nigeria}

The Federal Inland Revenue Services (FIRS) has monitored the BEPS project very closely. It has funded the final set of suggestions both directly and through ATAF. Listed below are some of the short term and long-term effects of the BEPS in Nigeria according to (PWC 2015):

i. Instant execution of changes to the OECD guidelines since regulation 11of the Nigerian TP regulations permit variations to the OECD guidelines to routinely apply.

ii. Improved inquiry of favored tax regimes and tax encouragements provided to Nigerian businesses to confirm occurrences where they have been granted improperly as well as whether the establishment of those incentives supplied any real economic gain or growth to the country.

iii. Possible regulatory and legislative alterations to include other suggestions that are not part of the OECD guidelines.

iv. An improved demand (by the FIRS) for financial and other information of offshore connected parties; this could comprise of demands made to the local affiliate (e.g. master file information) as well as demands made to the tax authorities of the Head Office (e.g. CBC reports) or a non-resident affiliate through the system of the Convention on Mutual Administrative Assistance in Tax Matters.

v. Improved capacity of the FIRS to track and confront the occurrences of improper transfer pricing.

What should corporations operating in Nigeria do? Substance and consistency are the name of the game in this BEPS era. We suggest that MNEs:

a. Make sure that reported profits agree with value created in Nigeria;

b. Re-access their intercompany contracts and business models to assess the sustainability and length of such arrangements;

c. Take extra care to ensure the consistency of information provided to tax authorities across borders. Aligning TP: outcomes with Value Creation These action points would result in amendments to the existing OECD TP Guidelines for Multinational Enterprises and Tax Administrations.

The changes introduced to the OECD guidelines de-emphasize analysis of related party transactions based solely on contractual agreements and stress the need to consider the actual conduct of the parties.

\subsection{Theoretical Review}

This study was theoretically buttressed by the deterrence model of tax evasion by Allingham and Sandmo (1972). The theory expounds that taxpayers should try to optimize the utility of tax evasion by taking into consideration three main factors: the extent of their risk aversion, the size of disadvantage and the chance of being caught. This view emphasizes that if the advantage of evading tax is more than the disadvantage or the punishment, then the taxpayer could utilize it. Under this model, citizens are assumed to neither have civil responsibilities nor moral deduction for tax payments. Ratherl, they choose the ideal rate of tax evasion to maximize their anticipated utility. Tax evasion is a dangerous choice. A high remuneration resulting from tax evasion would be counterbalanced by disadvantages that would be forced by the tax authority if it is found. This connotes that taxpayers could be in favor of tax evasion, in as much as possible benefits are greater than possible losses; however, this would be measured by the degree of their risk aversion. As established in the prospect theory, people might prefer increased losses more than increased gains, depending on the perspective of the person. The irregularity between utility cost and profit could limit taxpayers from obtaining the best level of tax evasion.

Many studies discussed the theory of tax evasion by companies. For instance, Chen and Chu (2005) model income tax evasion by corporations, and Crocker and Slemrod (2005) developed an economic theory of corporate tax evasion. These studies relate the tax evasion tactic used by managers to increase the wealth of the owners or shareholders. Both studies viewed tax evasion as an illegal tax avoidance tactic. In essence, few theoretical studies have particularly discussed the theory of tax evasion by multinational companies. According to Gordon and Hines (2002), in contrast to individual taxpayers, it is uncommon for large corporations to commit tax evasion like deliberately understating revenue to tax authorities.

Further, Gordon and Hines (2002, p. 1970) conclude that 'very little is known about the determinants or magnitude of international tax evasion since the self-reported data that serve as the basis of analysis not surprisingly reveal nothing about it'. To a large extent, this conclusion suggests that MNEs use international tax avoidance rather than international tax evasion as an alternative to lessen their income tax liability. In contrast, several studies discuss the theory of tax avoidance by corporations. In a review of tax research, Hanlon and Heitzman (2010) briefly discuss the theory of corporate tax avoidance by citing four papers that 'provide theory and predictions about the relationships and incentives of the various parties (i.e., insiders, outside shareholders, and the state) in corporate tax avoidance settings.

According to Hanlon and Heitzman (2010), three of the four papers (i.e. Slemrod, 2004; Chen \& Chu, 2005; Crocker \& Slemrod, 2005) lay a theoretical foundation for understanding corporate tax avoidance in connection with 
agency framework, and one paper (i.e. Desai, Dyck, \& Zingales, 2007) introduces another perspective to the literature. However, only Slemrod (2004) and Desai, et al. (2007) are relevant to the discussion of the theory of tax avoidance by corporations. 41 Some other relevant studies are included in the discussion to clarify the idea introduced by the two papers. The theory of corporate tax avoidance discussed in this section applies to corporations in general, which could be multinational enterprises or domestic enterprises. The next section discusses the theory that underlies tax avoidance by MNEs according to existing literature.

\subsection{Empirical Review}

Universally, a quite number of studies have been carried out on the effect of Base Erosion and Profit Shifting on Revenue Generation. In Denmark, Cristea and Nguyen (2015) research found that with new empirical proof, that multinational establishmentse profit shifting device through transfer pricing manipulation is real and worrisome. Using data for the period 1999 - 2006 from Denmark, they found that there was significant evidence that Danish multinational firms shift profits from high-tax jurisdictions to low-tax jurisdictions by using transfer pricing manipulation.

A similar study was conducted in the United States by Dowd, Landefeld and Moore (2017) undertook a study on profit shifting of U.S. multinationals. The study adopts the HRA, but also states that the semi-log specification introduced by Hines and Rice (1994) has become a standard in the literature. Using a panel dataset of US tax returns, the researchers scrutinize the profit shifting behaviour of US multi-nationals over the period 20022012 and recommend the reflection of a non-linear relation between reported profits and tax rate.

Another study was conducted by Crivelli, Mooij and Keen (2015) investigated base erosion, profit shifting and developing countries. The study made use of panel data for 173 developed and developing countries to determine whether profit shifting is an important issue for developing countries. The results of the study suggest that profit shifting is disadvantageous to developing countries as much as it is disadvantageous to developed countries. However, the authors acknowledge that the conclusion may not be robust to some extent because there is scarce firm-level data for developing countries. This suggests that recent research that focuses on developing countries still encounters data-related issues.

Using financial data for 100 Malaysian-listed corporations for 2009-2011, Salihu, Annuar and Obid (2015) examined the relationship between foreign investors' interests and tax avoidance by means of profit shifting in Malaysia. Using a generalized method of moment (GMM) estimator, they demonstrate that the relationship between foreign investors' interests and tax avoidance is significantly positive among large Malaysian corporations. In the study of Olaoye and Aguguom (2017) on tax base erosion and profit shifting through transfer pricing evidenced from Nigeria, from the perspective of tax avoidance and profit shifting manipulative. Content analysis research approach where some academic papers, scholarly journals, online research database, and other related materials were reviewed, furthermore, it is evidenced that multinational enterprises manipulate transfer pricing in order to shift their profits sandwiched between high- and low-tax jurisdictions is a global phenomenon.

A study by Purba (2018) investigates base erosion and profit shifting in Indonesia using confidential tax return data for the period 2009-2015. The study specifically investigates whether foreign-owned Indonesian companies (FOICs) shift profits out of Indonesia by examining the effect of the difference in statutory corporate tax rates (STR) between the source country of investment and Indonesia on the profit reported by FOICs in Indonesia. Through the analysis carried out through regression, the result reveals that the lower the tax rate of the parent country relative to Indonesia, the lower the profit reported by FOICs, providing empirical evidence consistent with the profit shifting occurring in Indonesia. The result also shows that a tax rate that is one percentage point lower in the parent country reduces the accounting profit and taxable income reported by FOICs in their Indonesian tax returns. Lastly, the result reveals that while FOICs use both channels to shift profits, transfer pricing plays a more significant role than debt financing.

Folayan and Adeniyi (2018) investigate the effect of tax evasion on government revenue generation in Oyo State using a structured questionnaire. sample of one hundred and sixty-five (165) respondents who were randomly selected across the state while secondary data were gathered from the National Bureau of Statistics (NBS), Office of Budget and Economic Planning, and Internal Revenue Office using data from 2011- 2016. Data collected were analyzed via regression analysis. The findings showed that the amount of Internally Generated Revenue (IGR) between 2011 and 2016 did not meet the estimated revenue as it was expected. The results also revealed that tax evasion has an adverse effect on government revenue generation in Oyo state which typically results in revenue loss. The implications of these results may cause an inevitable distraction to the potential performance of government in the public sector; therefore, threatening its competence to finance public expenditure and undermining the legitimacy of government due to non-compliance to pay tax.

Studies like Dowd, Landefeld and Moore (2017), Crivelli, Mooij and Keen (2015), Salihu, Annuar and Obid (2015) and Purba (2018) have been conducted in this context in the developed countries. However, based on the researcher's knowledge, just a single study, Olaoye and 
Aguguon (2017), has been conducted on base erosion and profit shifting in Nigeria. Interestingly, this study was a qualitative one hence, an empirical study on the effects of base erosion and profit shifting on revenue generation is lacking to the best of the researchers' knowledge. This, therefore, constituted the premise on which this study was developed to examine the effect of base erosion and profit shifting on revenue generation in Nigeria and equally investigate the effect of tax revenue on the economy of Nigeria.

\section{Research Method}

This study employed an ex-post facto research design. This study used a secondary source to obtain data from the CBN Statistical Bulletin of 2017, Security and Exchange Commission (SEC) annual bulletin and the Federal Inland Revenue Services (FIRS) annual reports for various periods under the study. Quarterly data were gathered on tax revenue and Gross Domestic Product of Nigeria from 2013-2017. Specifically, data collected on tax revenue were divided into PRE-BEPS (from the third quarter of 2013 to the third quarter of 2015) and POST-BEPS (from the fourth quarter of 2015 to the fourth quarter of 2017). The study covers nine quarters before the introduction of BEPS project and nine quarters after the introduction of the BEPS project. Descriptively, mean was used to explain the differences in the performance variables while inferential statistics of paired sampled t-test and simple linear regression were used as the analysis methods. The test of significant difference between the two means would be carried out with the calculated t-value is:

$$
t=\frac{x 1-x 2}{\sqrt{\frac{s_{1}}{n 1}+\frac{s_{1}}{n 2}}}
$$

Where:

$\mathrm{X} 1=$ Mean of Post-BEPS revenue generation of the federal government used as a case study

$\mathrm{X} 2=$ Mean of Pre-BEPS revenue generation of the federal government used as a case study

S2 = variance of the Post-BEPS revenue generation of the federal government used as a case study

$\mathrm{S} 2=$ variance of the Pre-BEPS revenue generation of the federal government used as a case study
N1 $=$ number of Post-BEPS years

N2= number of Pre-BEPS years

The calculated P-value (significant level) is compared with 0.05 level of Significance

Decision rule

Accept Ho if Calculated P-value $>0.05$.

Reject Ho if Calculated P-value $<0.05$.

OR

Reject Ho if the $\mathrm{t}$ - calculated value is greater than the $\mathrm{t}$ tabulated value at $5 \%$ level of significance.

In the same vein, the regression equation is given thus:

$$
\mathrm{GDP}=\beta_{0}+\beta_{1} \mathrm{TAR}+\mathrm{U}_{\mathrm{t}}
$$

Where:

$\beta_{0}=$ Intercept

$\beta_{1}=$ Coefficient of the Independent variable

$$
\mathrm{Ut}=\text { Error term }
$$

The a-prior expectation of the model stated below indicated that tax revenue is expected to have a positive relationship with Gross Domestic Product.

$$
\frac{\Delta \mathrm{GDP}}{\Delta \mathrm{TAR}}=>0
$$

\section{Results and Discussion}

\subsection{Results}

The outcome in table 1 revealed a mean value of 225.191 and a standard deviation of 263.165. Based on the subtraction method, it implies that tax revenue in Nigeria before the introduction of Basic Erosion Profit Sharing (BEPS) was lower than tax revenue after the introduction of Basic Erosion Profit Sharing (BEPS) with 225.191 billion. The t-statistics and p-value reported to be 2.567 and 0.033 respectively implies that there is a positive significant difference between tax revenue before the introduction of Basic Erosion Profit Sharing (BEPS) and tax revenue after the introduction of Basic Erosion Profit Sharing (BEPS) in Nigeria. Put differently. This implies

\begin{tabular}{|c|c|c|c|c|c|c|c|c|c|}
\hline & & \multicolumn{5}{|c|}{ Paired Differences } & \multirow{3}{*}{$\mathrm{t}$} & \multirow{3}{*}{ df } & \multirow{3}{*}{ Sig. } \\
\hline & & \multirow{2}{*}{ Mean } & \multirow{2}{*}{ Std. Deviation } & \multirow{2}{*}{$\begin{array}{l}\text { Std. Error } \\
\text { Mean }\end{array}$} & \multicolumn{2}{|c|}{$\begin{array}{l}\text { 95\% Confidence Interval of the } \\
\text { Difference }\end{array}$} & & & \\
\hline & & & & & Lower & Upper & & & \\
\hline Pair 1 & $\begin{array}{l}\text { PREBEPS - } \\
\text { POSTBEPS }\end{array}$ & 225.1910 & 263.1650 & 87.7217 & 22.9044 & 427.4775 & 2.567 & 8 & .033 \\
\hline
\end{tabular}
that the Basic Erosion Profit Sharing (BEPS) has stimulated an increase in the tax revenue in Nigeria.

Table 1. Paired Sampled Test

Source: Data Analysis, 2019 
Table 2. Simple Linear Regression Dependent Variable: Gross Domestic Product (GDP

\begin{tabular}{|c|c|c|c|c|}
\hline Variable & Coefficient & Std Error & t-statistics & Prob. \\
\hline C & 5495.622 & 1976.530 & 2.780439 & 0.0123 \\
\hline TRE & 10.90303 & 2.081038 & 5.239228 & 0.0001 \\
\hline
\end{tabular}

R-Squared $=0.603956$

Adjusted R-Square $=0.581954$

Durbin Watson stat $=0.684357$

F-statistics $=27.44951$

Prob (F-statistics) $=0.000055$

Table 2 revealed the estimation result of the effect of tax revenue on Gross Domestic Product (GDP) in Nigeria for 20 quarters, spanning from the first quarter of 2013 to the last quarter of 2017. The outcome revealed that tax revenue exerts a positive effect on Gross Domestic Product (GDP) in Nigeria to the tune of $10.9030 \quad(p=0.0001<0.05)$. $\mathrm{R}$-square reported to be 0.6039 indicates that tax revenue accounted for about 60\% change in the Gross Domestic Product (GDP) of Nigeria, while the remaining of the change covered by $40 \%$ was as a result of other variables not addressed by this study. Likewise, the Prob(F-stat) of 0.0000 which was less than 0.05 proved the model to be fit.

\subsection{Discussion of Findings}

An attempt has been made to reveal the effects of the Basic Erosion Profit Sharing (BEPS) on revenue generation in Nigeria taking into cognizance the relationship between the tax revenue generated before and after the introduction of the BEPS projects in Nigeria. From the analysis carried out, it was discovered that there was a positive significant difference between tax revenue before and after the introduction of Basic Erosion Profit Sharing (BEPS) in Nigeria. A critical look at the estimation result, particularly the mean value, it could be discovered tax revenue generated before the introduction of BEPS was lower than the tax revenue generated after the introduction of BEPS. The reason why BEPS has stimulated an increase in the tax revenue might be attributed to the ability of the FIRS to identify and solve instances of abusive transfer pricing and take extra care to ensure consistency of information provided to tax authorities across borders. The inference of this discovery is that the introduction of BEPS has engendered an increase in the tax revenue in Nigeria.

Another discovery made was that tax revenue exerts a positive effect on Gross Domestic Product (GDP) in Nigeria. This means that tax revenue has contributed tremendously to the economy of Nigeria. In relation to other studies, the outcome of this study corroborates the findings of Crisea and Nguyen (2013) and Olaoye and Aguguom (2017), that there was significant evidence that Danish multinational firms shift profits from high-tax jurisdictions to low-tax jurisdictions by using transfer pricing manipulation. They equally discovered that the underlying goal of multinational firms to maximize profit margins go beyond taking advantage of tax avoidance gaps to exploitative tendencies, depriving countries of legitimate tax revenues, and gain undue advantage over their operational host countries.

\section{Conclusions and Recommendations}

Base erosion typically occurs when multinational organizations engage in cross-border transactions that will shift income or expenses from one tax jurisdiction to another. The tax strategies employed to reduce an organization's overall tax burden give rise to a zero-sum game at the jurisdictional or county level, where one country will lose tax revenues and another will gain revenues. Thus, it is clear that international corporate taxation remains seriously dysfunctional. This was the crux of this study to ascertain if the introduction of BEPS has improved revenue generation in Nigeria. Based on the findings, it could be established that BEPS has an inbuilt mechanism to improve revenue generation in Nigeria. Thus, it was recommended that multinationals and other firms should willingly comply with regulations on tax revenue and transfer pricing. There is an urgent need to review tax planning activities to ensure compliance with Nigeria's new transfer pricing regulations being enforced by FIRS. It was also recommended that the multinationals carry out all-inclusive based BEPS risk assessment procedures to ensure that the implementation of any of the action plans will not lead to negative tax impact. Finally, FIRS and multinationals should try to overcome evolving issues in Nigerian transfer pricing management.

\section{REFERENCES}

[1] Adams, L., \& Drtina, R. (2010). Multinational Transfer Pricing: Management Accounting Theory Versus Practice. Management Accounting Quarterly, 11(3), 22

[2] Allingham, M. G., \& Sandmo, A. (1972). Income Tax Evasion: A Theoretical Analysis. Journal of Public Economics, 1(3), 323-338.

[3] Buettner, T., Overesch, M., Schreiber, U., \& Wamser, G. (2012). The Impact of Thin Capitalization Rules on the Capital Structure of Multinational Firms. Journal of Public Economics, 96(11), 930-938.

[4] Chen, K.-P., \& Chu, C. Y. C. (2005). Internal Control versus External Manipulation: A Model of Corporate Income Tax Evasion. RAND Journal of Economics, 36(1), 151-164

[5] Cristea, A., \& Nguyen, D. (2015). Transfer Pricing by Multinational Firms: New Evidence from Foreign Firm Ownerships. American Economic Journal: Economic Policy, 8(3), 170-202.

[6] Crivelli, E., De Mooij, R. A., \& Keen, M. M. (2015). Base 
Erosion, Profit Shifting and Developing Countries. Washington, DC: International Monetary Fund.

[7] Crocker, K. J., \& Slemrod, J. (2005). Corporate Tax Evasion with Agency Costs. Journal of Public Economics, 89(9), 1593-1610.

[8] Desai, M. A., Dyck, A., \& Zingales, L. (2007). Theft and Taxes. Journal of Financial Economics, 84(3), 591-623.

[9] Dowd, T., Landefeld, P., \& Moore, A. (2017). Profit Shifting of U.S. Multinationals. Journal of Public Economics, 148(Suppl C), 1-13.

[10] Folayan. D, O., \& Adeniyi A. G. (2018). Effects of Tax Evasion on Government Revenue Generation in Oyo State, Nigeria. European Journal of Accounting, Auditing and Finance Research, 6(1), 76-89.

[11] Gordon, R. H., \& Hines, J. R. (2002). International Taxation. In A. J. Auerbach \& M. Feldstein (Eds.), Handbook of Public Economics. Amsterdam, Netherlands: North Holland

[12] Hanlon, M., \& Heitzman, S. (2010). A Review of Tax Research. Journal of Accounting and Economics, 50(2), 127-178.

[13] Hebous, S., \& Johannesen, N. (2015). The Role of Tax Havens in International Trade with Services. Cesifo Working Paper, 5414.

[14] Hines J., \& Rice, E. (1994). Foreign Tax Havens and American Business. Quarterly Journal of Economics, 109(1), 149-182.

[15] Hines, J.R. (2014). How Serious a Problem is Base Erosion and Profit Shifting? Canadian Tax Journal, 62(2), 443-53.

[16] Huizinga, H., \& Laeven, L. (2008). International Profit Shifting Within Multinationals: a Multicounty Perspective. Journal of Public Economics, 92(1), 1164-82.

[17] Johannesen, N., Tørsløv, T., \& Wier, L. (2016). Are less developed countries more exposed to multinational tax avoidance? Method and evidence from micro-data (WIDER Working Paper No. 2016/10). Helsinki, Finland: World Institute for Development Economics Research.

[18] Karkinsky, T., \& Riedel, N. (2012). Corporate Taxation and the Choice of Patent Location within Multinational firms. Journal of International Economics, 88(2), 176-85.

[19] KPMG. (2015). Base Erosion and Profit Shifting: Explanatory Note and Implication

[20] Mutti, J. \& Grubert, H. (2004). Empirical Asymmetries in Foreign Direct Investment and Taxation. Journal of International Economics, 62(2), 337-358.

[21] OECD (2014). Two-Part Report to G20 Development Working Group on the Impact of BEPS in Low Income Countries. Paris: OECD Publishing.

[22] OECD (2015a). Measuring and Monitoring BEPS, Action 11: 2015 Final Report. Paris: OECD Publishing.

[23] OECD (2015b). Designing Effective Controlled Foreign Company Rules, Action 3: 2015 Final Report. Paris: OECD Publishing.

[24] OECD (2015c). Economic survey of South Africa.
Available at: www.oecd.org/eco/surveys/South-Africa-OE CD-economic-survey-overview.pdf(accessed14 September 2018).

[25] Olaoye, S.A \& Aguguom, T.A. (2017). A Tax Base Erosion and Profit Shifting Through Transfer Pricing: Evidence from Nigeria. Journal of Business Administration and Management Sciences Research, 6(1), 001-012.

[26] Plasschaert, S. (1979). Transfer Pricing and Multinational Corporations: An Overview of Concepts, Mechanisms, and Regulations. New York: Praeger.

[27] Purba, A. (2018). Base Erosion and Profit Shifting In Indonesia. An Unpublished Thesis Submitted to The Australian National University. [Online] Available at https://openresearch-repository.anu.edu.au/bitstream/1885/ 148758/1/Arnaldo-Purba\%20Thesis\%202018.pdf.

[28] Purba, A. (2018). Cross-Border Profit Shifting: Evidence from Indonesia. [Online] Available athttps://www.busines s.unsw.edu.au/About-Site/Schools-Site/Taxation-BusinessLaw-Site/Documents/42-Purba-Tran-ATTA2018.pdf.

[29] PWC. (2015). Impact of the OECD BEPS Project on Companies Operating in Nigeria. Tax Alert

[30] Rainish, R., Mensz, P., \& Mohs, J. (2015). Global Financial Model for the Value Chain. Journal of Finance and Accountancy, 18 (1)

[31] Riedel, N. (2014). Quantifying International Tax Avoidance: A Review of the Academic Literature. Policy Paper 2. Oxford: European Tax Policy Forum.

[32] Salihu, I. A., Annuar, H. A., \& Obid, S. N. S. (2015) Foreign Investors' Interests and Corporate Tax Avoidance: Evidence from an emerging economy. Journal of Contemporary Accounting \& Economics, 11(2), 138-147.

[33] Shah, S. R. (2010). Marketing. Delhi: A. H. Wheeler and Co. Ltd

[34] Slemrod, J. (2004). The Economics of Corporate Tax Selfishness. National Tax Journal, 57(4), 877-899.

[35] UNCTAD (2015). World Investment Report 2015. Geneva: UNCTAD. UNCTAD (2015).www.imf.org/en/News/Artic les/2015/09/28/04/53/sp022216andwww.oecd.org/g20/topi cs/taxation/g20-finance-ministers-endorse-reforms-to-the-i nternational-tax-system-forcurbing-avoidance-by-multinati onal-enterprises.htm.

[36] Vijayakumar, S. (2016). What's base erosion and profit shifting? http://www.thehindu.com/news/cities/mumbai/w hatsbase-erosion-and-profit-shifting/article8404293.ece 